\title{
Between Lenin and Bandera: Decommunization and Multivocality in (post) Euromaidan Ukraine
}

\author{
Anna Kutkina \\ Helsingfors: Unigrafia 2020 \\ 224 sidor. ISBN $2243273 \mathrm{X}$
}

Recencerad av Per Anders Rudling [docent, Wallenberg Academy Fellow, Historiska institutionen, Lunds universitet, Per_Anders.Rudling@hist.lu.se]

Kutkinas avhandling är en studie av hur protesterna mot den korrupte men folkvalde presidenten Viktor Janukovytj tog sig politiska och sociala uttryck, och hur dessa processer reflekterar ett skiftande kulturellt landskap (s. iii). Studien baseras på 4,5 år av fältstudier i olika ukrainska regioner och på 64 intervjuer med olika deltagare i denna process (s. iii, 196). Kutkinas metodologi är »layered textual analysis», hennes teoretiska ramverk baserat på Michail Bachtins teori om heteroglossia och monologism såväl som Benedict Andersons koncept om föreställda gemenskaper (s. iii). Författaren vill gå bortom den forskning om Euromaidan som antingen varit faktabaserad och kvantitativt inriktad eller tagit formen av kritiska studier av den demokratiskt bristfälliga "avkommuniseringen». Hennes fokus är istället på »avkommuniseringens gräsrotsinitiativ» (s. 9), hur denna kommer till uttryck bland lokala aktivister. Eftersom avhandlingen lagts fram inom ämnet statsvetenskap är detta ett utpräglat interdisciplinärt arbete.

Kutkina använder Taras Kuzios definition av Sovjetunionen som ett imperium där Moskva och RSFSR definierade kärnan, och republikerna, däribland Ukraina, var "underordnade kärnan» (s. 42). Emedan detta kan framstå som oproblematiskt för den galiziska efterkrigsdiasporan, är det alls inte självklart varför Kyiv - och än mer Kharkiv, Dnipropetrovsk och Zaporizjzja - ska betraktas som sovjetstatens periferi snarare än dess kärna - något som bland andra Zbigniew Wojnowski (The Near Abroad: Socialist Eastern Europe and Soviet Patriotism in Ukraine, 1956-1985, 2017) och Andrij Portnov ("'The Heart of Ukraine'?: Dnipropetrovsk and the Ukrainian Revolution" i A. Wilson (red.) What Does Ukraine Think? s. 62-70) övertygande visat. Ukrainare var under Sovjetunionenens senare decennier överrepresenterade i den sovjetiska statsledningen (på 1970-talet var såväl Sovjetunonens parti- som 
statschefer ukrainare). En problematisering av begreppen kärna - periferi hade kunnat skänka analysen ytterligare djup.

Kutkina placerar kulten av den ukrainska radikalhögern i en post- eller antikolonial kontext och framställer den ledande mellankrigsfascistiska Organisationen av Ukrainska Nationalister (OUN), dess ledare Stepan Bandera och dess väpnade gren UPA (Ukrainska Upprorsarmén) som "primary symbols of anti-colonial transitioning» (s. 180). En djupare förtrogenhet med OUN:s intellektuella historia hade inbjudit till en problematisering även av en sådan tolkning, då ledande OUN-ideologer som Mychailo Kolodzyns'kyj och Jurij Lypa utvecklade doktriner för ett ukrainskt imperium som skulle innefatta såväl Kausasus som Centralasien.

Mer övertygande är Kutkinas argumentation att Euromaidan-omvälvningen inneburit att radikalnationalistiska symboler approprierats av stora delar av det ukrainska civilsamhället och "kommit att anta en ny, hegemonisk roll» där "nationalist» fătt en ny mening - som »hjälte, beskyddare och ukrainsk patriot» (s. 171). Baserat på Bachtin argumenterar författaren för att Ukrainas medborgare »befinner sig mitt i en process där deras olika politiska ställningstaganden artikuleras i form av artistisk 'dialogism'» (s. 172). För detta nya minne spelar myter, personer och symboler från just västra Ukraina, enkannerligen Galizien, en central roll: »for the first time since 1991, there occurred explicit mastering of the country's discursive and physical space by western Ukrainian symbols» (s. 193). Den minneslagstiftning som var ämnad att tillrättalägga historien och ena folket runt en uppbygglig patriotisk diskurs innebar en enkelriktad monolog från myndigheternas sida: „As of 2018, besides Ukrainian and international academic and media circles, no official, institutionalized opposition to glorification of the OUN and other nationalist figures existed in Ukraine» (s. 185). Trots att såväl lagstiftare och ett statligt minnesinstitut lagt betydande resurser på en ny uppsättning nationella hjältar var resultatet delvis ett annat än vad myndigheterna tänkt sig, då befolkningen inte fullt ut »internaliserade den statssanktionerade modellen i vilken en personkult (dvs. av Lenin) ersattes av en annan (dvs. av Bandera)» (s. 192).

Kutkina placerar rehabiliteringen av den ukrainska mellankrigsfascismen i en kontext av emancipation från Ryssland, där förhärligandet av Bandera och UPA bör ses i ljuset av försöken att skapa en negativ bild av Ryssland (s. 179). Här hade möjligen ytterligare historisk kontext varit välkommen; det faktum att OUN och UPA:s politiska våld i relativ ringa utsträckning riktades mot ryssar - utan framför allt mot polacker, judar och ukrainska politiska motståndare är en viktig bakgrund till varför rehabiliteringen av dessa grupper väckt så starka känslor i just Polen och Israel.

Författarens bakgrund till såväl Bandera- som Leninkulterna har en hel del uppseendeväckande faktafel. Hon hävdar bland annat att de monumentala Leninstatyrena kunde vara över ett hundra meter höga »occasionally topping 320 meters tall buildings such as the Palace of the Soviets in Moscow» (s. 88). Den största sovjetiska Leninstatyn var emellertid 27 meter, och det planerade Sovjeternas palats i Moskva blev aldrig byggt. Pravyi sektors röd-svarta flagga beskrivs genomgående som 
UPA:s flagga (s. 100, 141, 170). Blod-och-jord-fanan är emellertid OUN-Banderas flagga, introducerad i april 1941, två år innan UPA grundades. Efter att ha introducerat Bandera som UPA-ledare (s. 174) förvånas Kutkina av bokomslag där denne förefaller "berövad sin militäruniform: han är 'klädd' i jacka, skjorta och slips av modernt snitt, snarare än något från mitten av nittonhundratalet» (s. 175, appendix s. 64). Men Bandera var aldrig medlem i UPA, bar inte uniform - och satte inte sin fot i Ukraina efter 1934. Fotot hon så förvånas över är autentiskt och välkänt. Originalet kommer från en falsk ID-handling utfärdad för Stepan Bandera under hans alias Stefan Popel sommaren 1945 och användes av det ukrainska postverket som förlaga för de jubileumsfrimärken de gav ut till hundraårsdagen av hans födelse. Då representationen av just Lenin och Bandera är centrala teman i avhandlingen känns sådana kunskapsluckor speciellt problematiska.

Liknande problem uppstår i diskussionen om nationalistledaren Symon Petljura, vars porträtt dök upp på Självständighetstorget i Kyiv vid sidan av Bandera, ackompanjerat av en text som påstod att denne skulle ha dödats av en "Moskvabolsjevikisk agent» (s. 166, appendix s. 64). Mot Kutkinas analys av det ideologiska offernarrativet som sammanbinder ukrainska nationalister då och nu finns lite att invända. Vad som saknas är historisk kontext och kritisk granskning av myterna. Trots att den nationalistiska trossatsen att Petljuras mördare Schwartzbard var moskovitisk-bolsjevikisk agent aldrig bevisats är fiendebilden av "Moskva", juden och bolsjeviken ännu levande. Då denna 1919 och 1941 blev en förevändning för det politiska våld Petljuras och Banderas anhängare utövade mot den judiska befolkningen blir det extra viktigt för att skilja på anekdot och evidens.

Författaren undviker inte de "svåra» ämnena, varken UPA:s etniska våld eller lokal medverkan i förintelsen, och citerar forskare som företräder olika perspektiv och tolkningar - såväl internationella forskare som ukrainska statliga minnesadministratörer och minneslagstiftare finns representerade i litteraturlistan. Däremot är namn - ukrainska såväl som utländska - ofta felstavade. Författaren Juryj Andruchovytj blir "Adrukhovych» (s. 40), historikerna "Mykola Posivnycha» (s. 178) "Andrii Portnom» (s. 167) och Yuliya Yurchuk (s. 221, 223) får två olika stavningar, Grzegorz Rossliński-Liebe tre (s. 167, 181, 218). Undertecknad blir »RUDLING, Andres» (s. 219) - och den samförfattade artikeln felciterad både vad gäller författare och år $(\mathrm{s} .159-160,163,164)$. Inte heller personer och platser av central betydelse för den ukrainska nationalistiska traditionen förskonas från detta godtycke; befälhavaren för UPA-Nord Dmytro Kljatjkivs'kyj blir "Klyachkisvsky» (s. 174), Symon Petljura blir såväl "Symen Petlura» (s. 175) som "Semen Petliura» (s. 156) och hans tillfälliga huvudstad Vinnytsia blir "Vinnistia» (s. 174). Röda armé-officeren Mykola Sitjors (Shchors i proper engelsk translitteration) blir "Shjors» (appendix, s. 49).

Språkbehandlingen lämnar en del övrigt att önska, med betydande grammatiska och syntaktiska fel texten igenom. Bristande akribi tynger litteraturlistan. Titlar, förlag, utgivningsort ges godtyckligt, ibland anges stad, i andra fall land, till exempel "Netherlands», "Switzerland», "UK» eller "USA», slumpmässigt kursiverade. 


\section{PER ANDERS RUDLING}

Ofta saknas volym och nummer för tidskrifter. Då translittereringen inte följer det för engelskspråkiga texter gängse Library of Congress-systemet blir det ibland synnerligen idiosynkratiskt med titlar såsom »Proekt 'Ykrajina': Galychyna vYkrajinskij Revoljucii 1917-1921" och "Volodymyr Viatrovych i Ykrajinski Dekomunizacijni Zakony» (s. 214). Genom att underlåta språkgranska manuskriptet har förlaget gjort författarinnan en otjänst. Sammantaget bidrar detta - med rätt eller orätt - till att ge intrycket av ett hafsverk. Med ganska små medel, såsom en Chicago Manual of Style till hands och korrekturgranskning av kompetent språkgranskare hade en del av tillkortakommandena kunnat avhjälpas. Ett index hade inneburit en ytterligare förbättring. 